LAWRENCE LIVERMORE N A T IO N A L LABORATORY

\section{Aspects of the Tribology of the Plastic Bonded Explosive (PBX) 9404}

D. Mark Hoffman, Jeffrey B. Chandler

July 13,2004

Journal of Energetic Materials 
This document was prepared as an account of work sponsored by an agency of the United States Government. Neither the United States Government nor the University of California nor any of their employees, makes any warranty, express or implied, or assumes any legal liability or responsibility for the accuracy, completeness, or usefulness of any information, apparatus, product, or process disclosed, or represents that its use would not infringe privately owned rights. Reference herein to any specific commercial product, process, or service by trade name, trademark, manufacturer, or otherwise, does not necessarily constitute or imply its endorsement, recommendation, or favoring by the United States Government or the University of California. The views and opinions of authors expressed herein do not necessarily state or reflect those of the United States Government or the University of California, and shall not be used for advertising or product endorsement purposes.

This work was performed under the auspices of the U.S. Department of Energy by the University of California, Lawrence Livermore National Laboratory under Contract No. W-7405-Eng-48. 


\title{
Aspects of the Tribology of the Plastic Bonded Explosive (PBX) 9404*
}

\author{
D. Mark Hoffman and Jeffrey B. Chandler \\ High Explosive Applications Facility \\ Lawrence Livermore National Laboratory \\ Livermore, CA
}

\begin{abstract}
The coefficient of friction, $\mu$, of the plastic bonded explosive (PBX) 9404 was measured on stainless steel, aluminum, Teflon and the explosive itself as a function of temperature between ambient and $135^{\circ} \mathrm{C}$ at a rotational speed of $0.0025 \mathrm{rad} / \mathrm{sec}^{-1}$. An optical profilometer was used to analyze the mean surface roughness, $R_{a}$, of the various materials. PBX 9404 is a composite of the explosive 1,3,5,7- tetranitroazacyclooctane (HMX) chloroethyl phosphate (CEF) and nitrocellulose in an 96/3/3 weight ratio. The average roughness of the pressed explosive surface was $R_{a}=1.37 \mu \mathrm{m}$. The coefficient of friction for PBX 9404 on stainless steel of $\mathrm{R}_{\mathrm{a}}=0.40 \mu \mathrm{m}$ increased from 0.22 at ambient to 0.34 at $95^{\circ} \mathrm{C}$. Above this temperature $\mu$ decreased to about 0.23 at $125^{\circ} \mathrm{C}$. Similar behavior was observed with aluminum with $\mathrm{R}_{\mathrm{a}}=0.31 \mu \mathrm{m}$. The coefficient of friction increased from about 0.08 at ambient to 0.48 at $115^{\circ} \mathrm{C}$. Above this temperature, $\mu$ tended to decrease slightly. The coefficient of friction against Teflon of $\mathrm{R}_{\mathrm{a}}=0.054 \mu \mathrm{m}$ was sigmoidal, increasing from about 0.3 at ambient to about at $0.49 \pm 0.002$ above $115^{\circ} \mathrm{C}$. Against a PBX 9404 counter surface, the coefficient of friction averaged 0.54 over the entire test temperature range, but tended to increase during the measurement, probably due to adhesion of the nitrocellulose to itself.
\end{abstract}

\section{Introduction}

Serious explosive accidents have occurred as a result of oblique impact on a surface. Detonation is believed to result from frictional heating during skidding on the surface. Several tests to determine the onset of reaction due to oblique and crushing impact including skid tests [1], Susan tests [2] and Steven tests [3] have been developed by various organizations to evaluate this hazard. A small scale BAM friction test is often used to estimate the sliding force required to produce a reaction in an explosive on a ceramic plate [4]. Until recently most of these tests were done at ambient. In effort to understand the dominant microscopic mechanism of initiation during impact, Steven tests on LX-04 and PBX 9404 heated to $150-170^{\circ} \mathrm{C}$ were compared with ambient results. The results showed that LX-04 was much less sensitive to impact (impact threshold increased significantly: $45 \mathrm{~m} / \mathrm{s}$ at ambient to $>125 \mathrm{~m} / \mathrm{s}$ at $150^{\circ} \mathrm{C}$ ) while $\mathrm{PBX}-9404$ impact threshold increased only slightly (35 m/s at ambient to $48 \mathrm{~m} / \mathrm{s}$ at $150^{\circ} \mathrm{C}$ ) [3]. Models for initiation depend on shear, deformation and friction. Data for the modulus and ultimate properties of LX-04 is available [5-6] as a function of temperature, but friction data is limited to near ambient conditions [7-8]. Less information is available for PBX 9404 $[9,10]$. In a previous study the coefficient of friction for LX-04 on steel, Teflon and the explosive itself decreased with increasing temperature [11], consistent with the Steven 
test results. The present study sought to determine whether or not the coefficient of friction of PBX 9404 as a function of temperature was sufficiently different from LX-04 to correlate with the Steven test results on this explosive.

\section{Experimental}

\section{$\underline{\text { Friction measurements }}$}

Parallel plate fixturing for a Rheometrics Mechanical Spectrometer model 800 was modified to measure the torque associated with a given normal force on cylindrical disks of PBX 9404 explosive $2.530 \pm 0.0007 \mathrm{~cm}$ in diameter by $0.320 \pm 0.001 \mathrm{~cm}$ thick. Samples of the explosive were bonded to the removable aluminum plate of the upper fixture with Scotch double stick foam tape. The counter surface, except for PBX 9404 explosive to itself, was machined into a $5.08 \mathrm{~cm}$ diameter disk with a $2.02 \mathrm{~cm}$ diameter lower section which was secured into the lower RMS fixture. The test setup is shown in Figure 1. The test was started with no contact between the PBX 9404 and counter surface which was rotating. The rotational speed for all testing was $0.0025 \mathrm{rad} / \mathrm{s}$. Once the transducer had auto zeroed, the sample and foam tape were lowered to approximately $0.020 \mathrm{~mm}$ below the contact distance. Compression of the foam usually resulted in between 20-90 g normal force, $\mathrm{N}$, being applied to the counter surface which decreased slowly as the foam relaxed. The resulting torque, $\mathrm{T}$, increased slowly for a few seconds and leveled out. The coefficient of friction, $\mu$, was calculated from:

$$
\mu=3 \mathrm{~T} / 2 \mathrm{NR}
$$

where $\mathrm{R}$ is the radius of the explosive disk. Typical results for PBX 9404 on aluminum are shown in Figure 2. As can be seen in the figure, the coefficient of friction calculated according to equation 1 quickly becomes nearly constant, even though the normal force and torque may vary slightly. Toward the end of the 1 minute contact time, the sample was raised to a height slightly above the surface to insure that the normal force and torque values return to zero and the temperature was incremented $10^{\circ} \mathrm{C}$. A torque and normal force measurement was taken every 0.0375 second. A two-minute hold time was allowed during which time the contact position was redetermined so that approximately the same compression of the fixture could be obtained at the next temperature. After the 2 minute soak time, the next experiment began. All experiments with PBX 9404 explosive were conducted remotely in a 0.5 " thick remote steel cell to protect the operator from the unlikely possibility of an explosion. The experiments were automated using the Rheometrics Orchestrator program, except for the repositioning of the z-axis, which was accomplished by a remote electronic control switch, instead of the up-down switches on the instrument.

\section{Surface Profiles.}

Surface profilometry was preformed on PBX 9404 and the counter surfaces using a Conoscan 3000 instrument manufactured by Optimet Optical Metrology. This conoscopic holographic technique measures the interference of ordinary and 
extraordinary rays off the sample through a birefringent crystal against a calibration to produce a surface profile $[12,13]$. The roughness $R_{a}$ is the mean of the $z$-axis profile calculated from:

$$
\mathrm{R}_{\mathrm{a}}=(1 / \mathrm{L}) \Sigma_{\mathrm{i}}\left|\mathrm{z}\left(\mathrm{x}_{\mathrm{i}}\right)\right|
$$

where $\mathrm{z}\left(\mathrm{x}_{\mathrm{i}}\right)$ is the height of the surface at $\mathrm{x}_{\mathrm{i}}$ and $\mathrm{L}$ is the length over which the measurement was made. A typical example of the results of such measurements is shown in Figure 3 for pressed PBX 9404 explosive.

\section{Materials:}

PBX 9404 samples from lot \# C-120 were compression molded in a cylindrical die at $85^{\circ} \mathrm{C}$ and 30,000 psi for 3 three minute dwells with approximately 1 minute relaxation at atmospheric pressure between pressing cycles. The density of PBX 9404 pressed samples averaged $1.831 \pm 0.004 \mathrm{~g} / \mathrm{cc}$ with an average radius of $1.2652 \pm 0.0003 \mathrm{~cm}$. Stainless steel, aluminum and Teflon plates were machined from stock. Small amounts of flash at the edges of PBX 9404 were removed by sanding.

\section{Results and Discussion}

Figure 2 shows the normal force and torque measurements of PBX 9404 against aluminum at $85^{\circ} \mathrm{C}$. As was typical with aluminum, stainless steel, or Teflon, the sample and foam are compressed rapidly by the lowering of the cross head, resulting in rapid rise of the normal force followed by slow decay probably associated with creep and set of the foam tape. The torque and coefficient of friction increased slowly as the lower fixture rotates for about 5 seconds, probably also associated with the relaxation of the foam tape, the onset of motion at the interface and run up phenomena. Within a short time an almost constant value of $\mu$ is reached as the counter surface slides across the explosive. No evidence of a static peak in the friction measurements was observed for PBX 9404 on aluminum or stainless steel. Near the end of the measurement time, the cross head is raised so that the normal force and torque return to zero prior to incrementing the temperature.

Typical coefficient of friction data for PBX 9404 against each different substrate at $85^{\circ} \mathrm{C}$ are shown in Figure 4 . As can be seen in the figure, after run up, a limiting value of $\mu$ is observed for both metals and PTFE. PTFE shows a peak characteristic of a static value for $\mu$, followed by a nearly constant dynamic coefficient of friction. A dramatic change in the run up characteristics occurred with PBX 9404 on itself. Also the limiting coefficient of friction for the explosive on itself was above 0.5 and not always constant. This type of behavior is associated with nitrocellulose binder adhesion of to itself across the moving surfaces. A similar effect was observed in LX-04 on itself up to about $115^{\circ} \mathrm{C}$ [11]. 


\section{$\underline{\text { PBX } 9404 \text { on Stainless Steel }}$}

PBX 9404 is an explosive composed of approximately 3\% by weight nitrocellulose (11.8-12.2\% nitrogen), 3\% chloroethyl phosphate (CEF) plasticizer and 94\% by weight of a 70.5/23.5 mixture of class 1 and class 5 HMX explosive [14]. Usually a small amount of diphenyl amine is added as a stabilizer for nitrocellulose (NC). This explosive will react violently when a ceramic pin is dragged across its surface at a normal pressure of approximately 2.25 MPa (325 psi) [4]. The surface roughness $\left(\mathrm{R}_{\mathrm{a}}=\right.$ $1.37 \mu \mathrm{m}$ ) of one of the pressed PBX 9404 pellets is shown in Figure 3. Figure 5 shows the coefficient of friction calculated from equation 1 as a function of time from about 20 seconds into each test run until just before the normal force was removed. In most cases the friction coefficient was reasonably constant at a given temperature. Only near the maximum value for $\mu\left(95^{\circ} \mathrm{C}\right)$ do the coefficients deviate more than a few percent over the time of the measurement. The average torque and normal force for each measurement are plotted in Figure 6. As can be seen from the figure, for a deformation of approximately $0.02 \mathrm{~mm}$, the normal force decreased with temperature from about $250 \mathrm{~g}$ to just slightly over $50 \mathrm{~g}$ at $135^{\circ} \mathrm{C}$. The torque follows the normal force, varying from 40 g-cm to 6 g-cm. Estimates of the coefficient of friction for PBX 9404 on stainless steel were made from the average of the traces in Figure 5. The results are plotted along in Figure 6. As can be seen from the figure, PBX 9404 passes through a maximum friction coefficient at about $95^{\circ} \mathrm{C}$. The counter surface was weighed before and after these tests and less than $1 \mathrm{mg}$ of explosive had been transferred to the stainless steel indicating minimal wear under these conditions.

It has been observed that the friction coefficient often follows the viscoelastic loss modulus of polymers [15] and composites [16] on metals. The viscoelastic properties of nitrocellulose and several plasticizers, though not CEF, have been reported $[17,18]$ and the loss modulus of PBX 9404 has also been measured [10], however no peak was observed in or around $95^{\circ} \mathrm{C}$.

\section{$\underline{\text { PBX } 9404 \text { on Aluminum }}$}

The dynamic coefficient of friction of PBX 9404 on aluminum at representative temperatures is shown in Figure 7 . Values of $\mu$ were nearly constant after the initial run in (not shown). Only values of $\mu$ at 125 and $135^{\circ} \mathrm{C}$ were not nearly constant during the measurement. The standard deviation in $\mu$ is about the same as for the stainless steel counter surface. Figure 8 is a plot of the average friction coefficient for PBX 9404 on aluminum over the temperature range tested. Friction at the Aluminum/PBX 9404 interface increased quickly above $35^{\circ} \mathrm{C}$ from about 0.1 to about 0.35 at $45^{\circ} \mathrm{C}$ then continued to increase slowly up to 0.48 at $115^{\circ} \mathrm{C}$ followed by a slight decrease at $125^{\circ} \mathrm{C}$. It is interesting to note that the loss modulus of PBX 9404 shows a peak at about $30^{\circ} \mathrm{C}$ consistent with the increase in friction at about this temperature [10]. 


\section{PBX 9404 on Polytetrafluoroethylene (PTFE)}

Teflon (PTFE) is used in shock and impact experiments to mock up the impact characteristics of an explosive [19]. PTFE is well known for its low friction coefficient against metals and hard surfaces [20]. The mechanism of friction reduction on hard surfaces is due to transfer of a thin PTFE film to the hard substrate which serves as a lubricant. The Teflon used in these experiments would not retain its shape over the temperature range so it was etched with tetra etch surface treatment and bonded to an aluminum plate using Epon 815/T9 epoxy/amine adhesive. Unfortunately, both surfaces were etched so the interface was etched PTFE rather than PTFE. Since PBX 9404 is a relatively soft surface, the film transfer mechanism proposed for metals may not be effective. As seen in Figure 9, PTFE is ineffective as a lubricant for PBX 9404. Interestingly enough, these measurements showed a pronounced static peak. The peak was $10-20 \%$ greater than the dynamic coefficient at temperatures up to $95^{\circ} \mathrm{C}$. Above this temperature the static peak dropped to about $5 \%$ of the dynamic coefficient of friction. This peak appears to be associated with the surface treatment of the PTFE. In LX-04 run against untreated PTFE, no peak was observed. However when LX-04 was tested against etched PTFE, the peak appeared. The effect was short lived and the dynamic coefficient returned to a reasonably constant value shortly after the maximum was reached.

As the temperature increased, the dynamic coefficient of friction takes a sigmoidal shape as seen in Figure 10. From a relatively low value of $0.25 \pm 0.01$ at 25 to $35^{\circ} \mathrm{C}$, the coefficient rises steadily to about $0.49 \pm 0.01$ at $115^{\circ} \mathrm{C}$ and above. In PBX 9404 PTFE does not act as a lubricant at all and becomes worse with increasing temperature. PTFE undergoes a solid-solid phase transition at approximately $19^{\circ} \mathrm{C}$ [21] which is too low to be responsible for the any change in friction behavior in the temperature range tested. However, the loss modulus peak in PBX 9404 occurred at $30^{\circ} \mathrm{C}$, about where the coefficient of friction begins to increase.

\section{$\underline{\text { PBX } 9404 \text { on itself }}$}

Since explosives often fracture and rubblizes on impact [18], the friction behavior of PBX 9404 explosive against itself is of interest. Since only $2.54 \mathrm{~cm}$ diameter samples of PBX 9404 were available, the lower explosive sample was attached to an aluminum insert with double stick tape. The friction coefficient of PBX 9404 against itself was quite high at ambient, $\mu\left(25^{\circ} \mathrm{C}\right)=0.562$. Figure 11 shows the traces of the coefficient of friction of PBX 9404 against itself. Values of $\mu$ were reasonably constant for only the first three temperature increments $\left(25-45^{\circ} \mathrm{C}\right)$. At $50^{\circ} \mathrm{C}$ and above, the coefficient increased for almost the entire 60 seconds of the measurement. This probably indicates that the nitrocellulose binder is adhering to itself across the interface. Unlike LX-04 [9], where the adhesion across the interface stopped above $100^{\circ} \mathrm{C}, \mathrm{PBX} 9404$ continues to show the hign, non-constant friction coefficients up to $135^{\circ} \mathrm{C}$. Figure 12 shows the average value of $\mu$ as a function of temperature with error bars three times the standard deviation in $\mu$ used to approximate the increase in the coefficient between 55 and $135^{\circ} \mathrm{C}$. During deformation and rubbilization, the increase of frictional heating of PBX 9404 
against itself would tend to the increase the sensitivity of the explosive to this type of initiation mechanism at elevated temperatures.

\section{Conclusions}

The parallel plate technique is an effective and simple way of estimating the coefficient of friction for PBX 9404 explosive on a variety of substrates as a function of temperature. No dramatic decrease in $\mu$ of PBX 9404 on aluminum, stainless steel, Teflon and the explosive itself as a function of temperature was observed. Thus no substantial effect due to friction on impact sensitivity of this explosive at high temperatures should be observed, consistent with results at high temperature in the Steven test [3].

\section{Acknowledgements}

Funding for this effort was provided by Steve Chidester of Defense Technologies Engineering Division and was greatly appreciated. The Conoscope 3000 surface profiles were performed by Jerry Benterou and Ron Chanbers. Jerry Benetrou also assistance with their interpretation. PTFE, RM-04-BR and stainless steel samples were machined from stock by Kou Moua with advise from Jeff Wardell. Don Burns modified the electronics on the RMS-800 so that the transducer and upper fixture could be raised and lowered from outside the explosive cell. Discussions with Steve Chidester, Steve DeTeresa, Bruce Cunningham, Joe Zaug, Craig Tarver, and Jonathan Crowherst are greatfully acknowledged.

\section{References}

1. R. J. Slape, MHSMP-84-22, Rev.1, “The Material Qualification Tests Description and Criteria”, Mason and Hanger-Silas Mason Co., Pantex Plant, June 1984.

2. L. G. Green and A. M. Weston, "Data Analysis of the Reaction Behavior of Explosive Materials Subjected to Susan Impact Tests”, UCRL-13480, University of California, Lawrence Livermore National Laboratory, Livermore, CA (1971).

3. L.L. Switzer, K. S. Vandersall, S.K. Chidester, D.W. Greenwood and C.M. Tarver, "Threshold Studies of Heated HMX-Based Energetic Material Targets using the Steven Impact Test”, UCRL-JC-152300, University of California, Lawrence Livermore National Laboratory, Livermore, CA (July 1, 2003).

4. L. R. Simpson and M. F. Foltz, "LLNL Small-Scale Friction Sensitivity (BAM) Test”, UCRL-ID-124563, University of California, Lawrence Livermore National Laboratory, Livermore, CA (June 1996).

5. D. M. Hoffman, "Dynamic Mechanical Signatures of Viton A and Plastic Bonded Explosives Based on This Polymer”, Polym. Eng. Sci., 43, 139 (2003).

6. W. Moen, unpublished results (1977).

7. K. G. Hoge, "Friction and Wear of Explosive Materials”, UCRL-50134, University of California, Lawrence Livermore National Laboratory, Livermore, CA (Sept. 1, 1966). 
8. K. G. Hoge, "Friction and Viscoelastic Properties of Highly Filled Polymers: Plastic-Bonded Explosives”, UCRL 70588 rev 1. University of California, Lawrence Livermore National Laboratory, Livermore, CA (Feb. 5, 1968).

9. J.R. Anthony and R.W. Ashcraft, Coefficient of static friction between explosives and machined surfaces”, Mason and Hanger-Silas Mason Co., Pantex Plant, Amarillo, TX, (1979).

10. B.M. Dobratz and P.C. Crawford, "LLNL Explosives Handbook”, UCRL 52997, University of California, Lawrence Livermore National Laboratory, Livermore, CA (Jan 31, 1985).

11. D.M. Hoffman and J.B. Chandler, "Aspects of the Tribology of the Plastic Bonded Explosive LX-04,” submitted to Prop. Explosives Pyrotech.

12. Conoscan 3000 operating instructions, Optimet Instruments, LTD., Appendix A

13. K. Buse and M. Luennemann, "3D Imaging: Wave Front Sensing Utilizing a Birefringent Crystal”, Phys. Rev. Letts., 85, 3385 (2000).

14. RM 252336-2-P5 “Material Specification for PBX 9404 Molding Powder”, University of California, Lawrence Livermore National Laboratory, Livermore, CA (June 26, 1963).

15. K.C. Ludema and D. Tabor, "The Friction and Visco-elastic Properties of Polymeric Solids”, Wear, 9, 239 (1966).

16. K. Friedrich, Z. Lu and A.M. Hager, "Overview on polymer composites for friction and wear application”, Theor. Appl. Fracture Mech. 19, 1 (1993)

17. R.C. Warren, "Mechanical relaxations in plasticized nitrocellulose”, Polym. 29, 919 (1988)

18. R.C. Warren, "The effect of aging and annealing on the physical properties of nitrocellulose plasticized with nitroglycerine”, Polym. 31861 (1990).

19. J.W. Forbes, P. A. Urtiev, C.M. Tarver and F. Garcia. "Hugoniot of Polytetrafluoroethylene (Teflon) at Initial Temperature of $250^{\circ} \mathrm{C}$ ”, UCRL-JC135387 Abs. University of California, Lawrence Livermore National Laboratory, Livermore, CA (1998).

20. I.M. Hutchings, “Tribology” CRC Press (London) Section 3.8, "Friction of Polymers”, pp 51-57 (1992).

21. H. Tadokoro, "Structure of Crystalline Polymers, John Wiley \& sons, NY (1979) pp 15-16 and 157-159.

22. R.R. Bernecker, H.W. Sandusky, A.R. Clairmont, Jr., "Deflagration-toDetonation Transition Studies of Porous Explosive Charges in Plastic Tubes," Seventh Symposium (International) on Detonation,NSWC MP 82-884, Naval Surface Weapons Center, US Naval Academy, Annapolis, MD June 16-19, 1981 


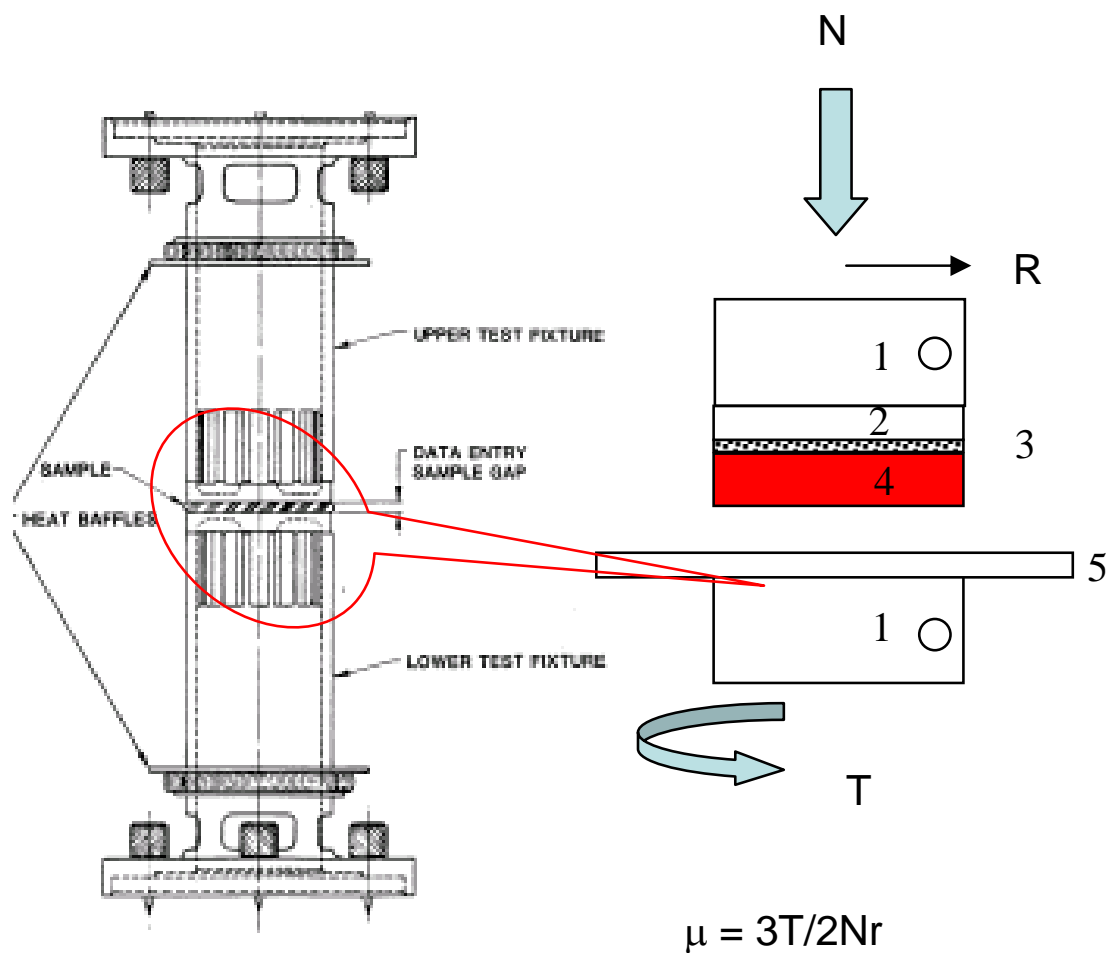

Figure 1. A friction measurement apparatus was developed based on the parallel plate fixtures for the Rheometrics Mechanical Spectrometer Model 800. In the figure $1=$ upper and lower test fixture, 2 = removable aluminum plate which is secured into the upper fixture by tightening the screw represented by a circle, $3=3 \mathrm{M}$ foam adhesive tape to aid in sample (4) /counter surface (5) alignment.

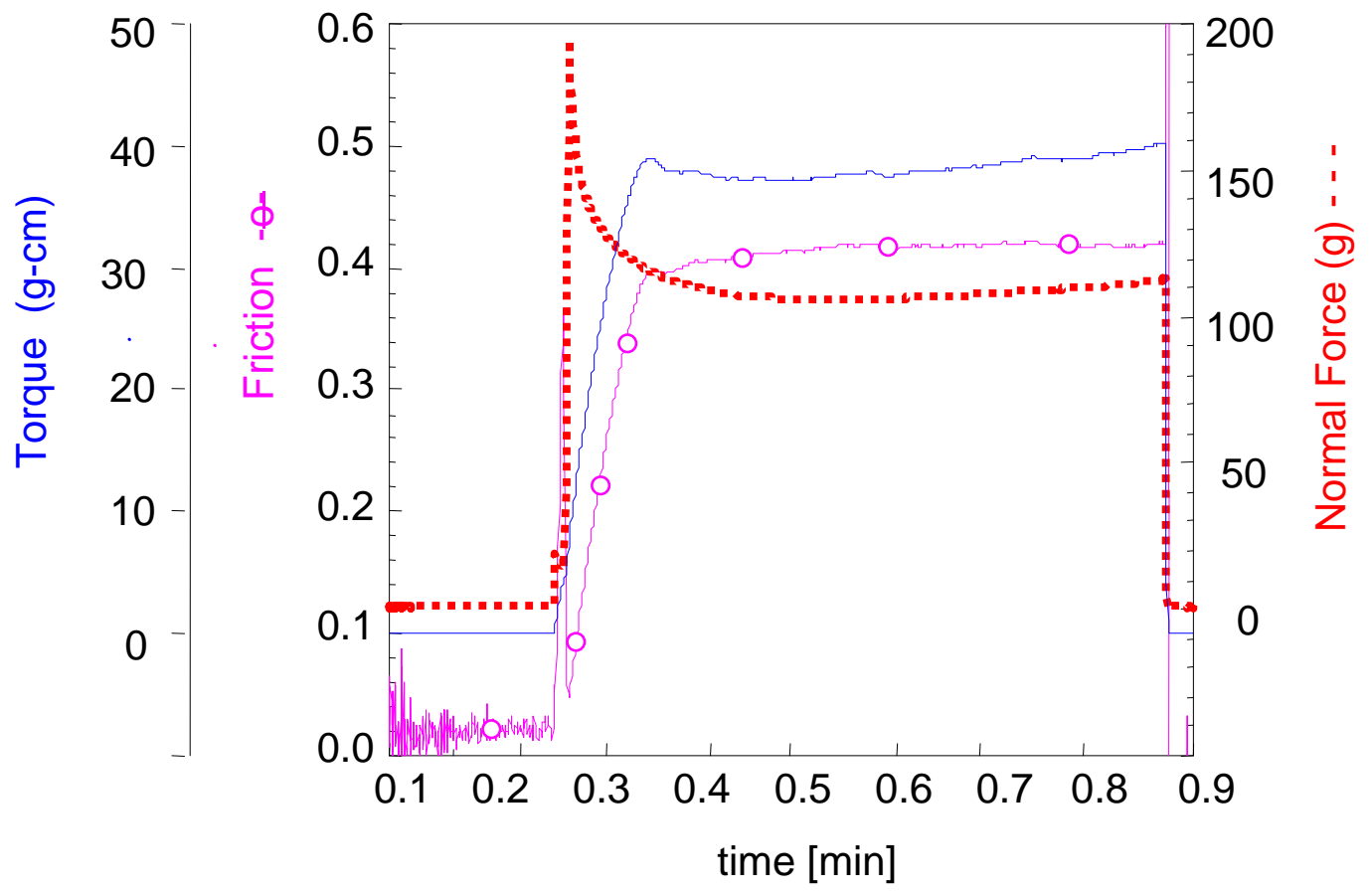

Figure 2. Typical results from torque and normal force measurements for PBX 9404 on Aluminum at $85^{\circ} \mathrm{C}$. 


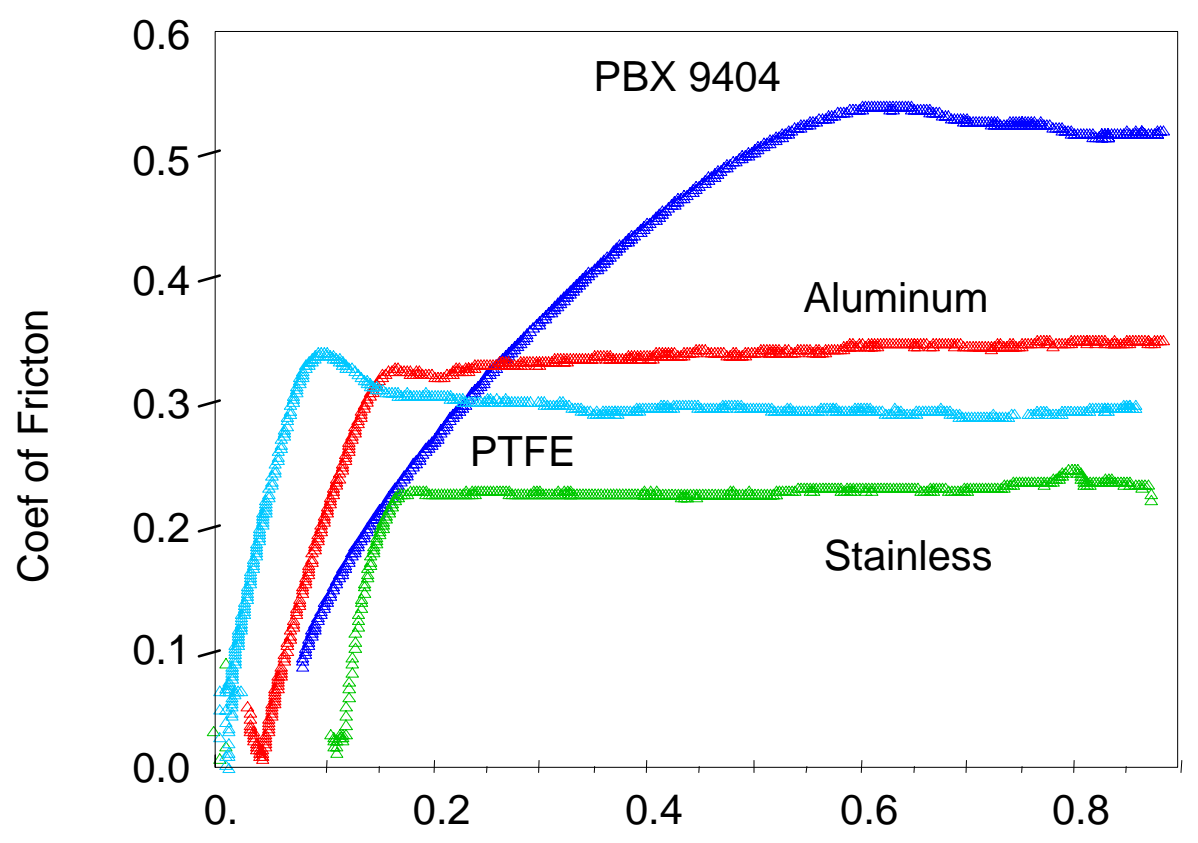

time [min]

Figure 3. The coefficient of friction as a function of time for PBX 9404 came to a nearly constant value on the different counter surfaces at $55^{\circ} \mathrm{C}$ except for the explosive on itself.

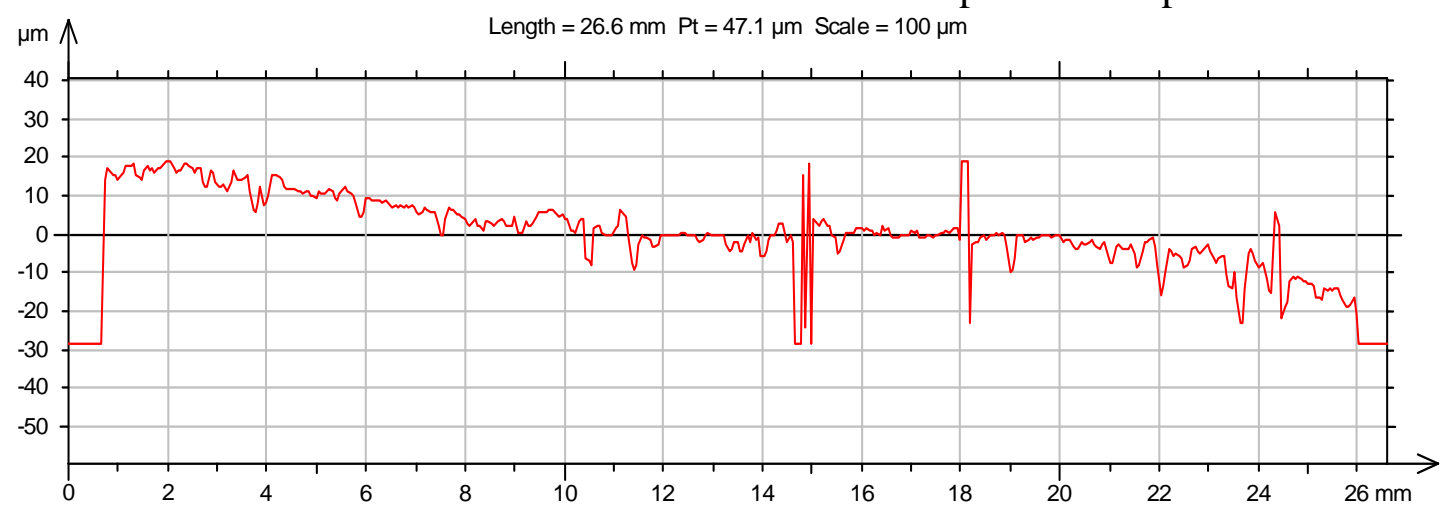

Figure 4. This profile of pressed surface of PBX-9404 explosive gave $R_{a}=1.37 \mu \mathrm{m}$. 


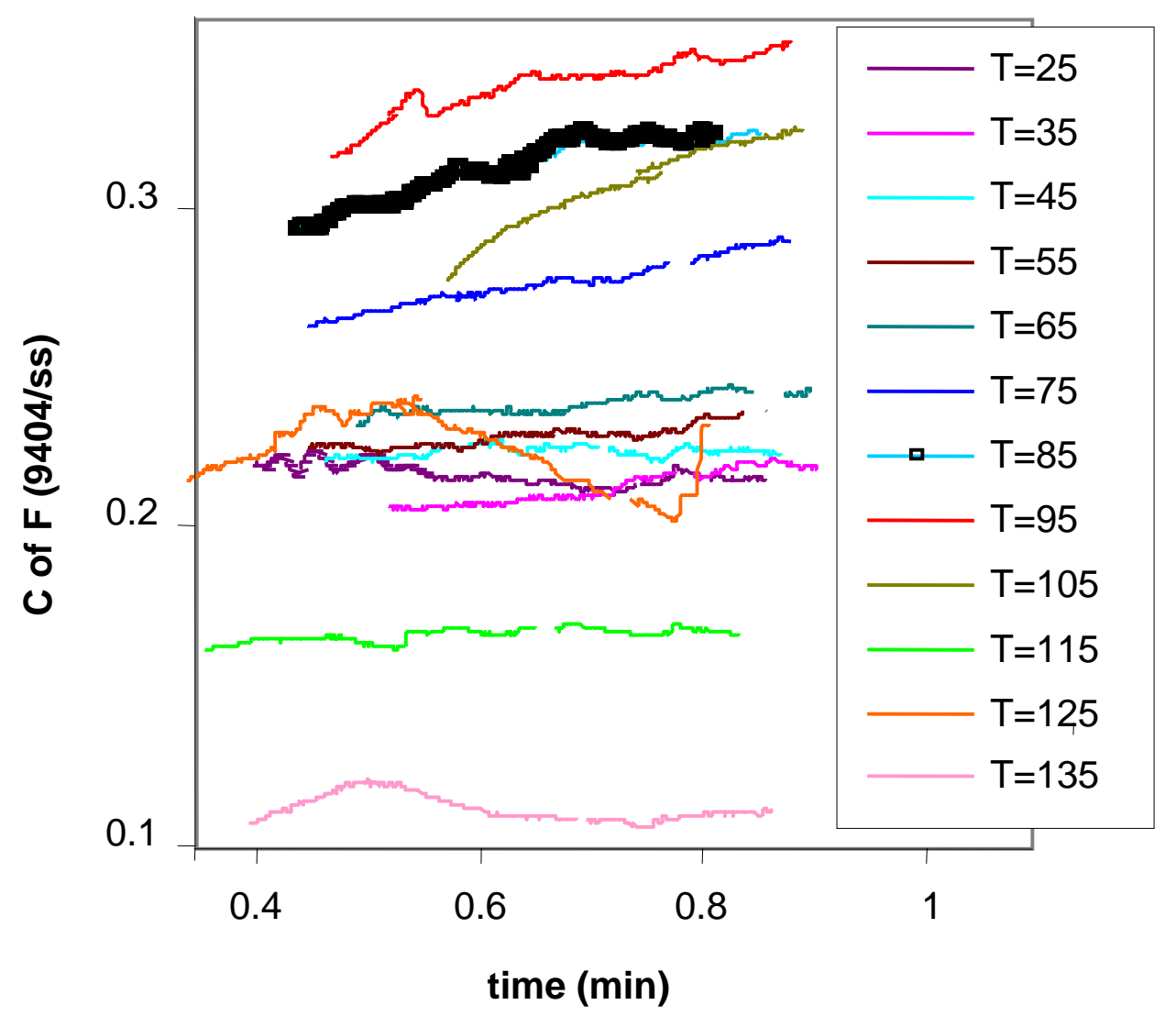

Figure 5. The dynamic coefficient of friction for PBX 9404 on steel at each temperature was nearly constant after an initial run up (not shown).

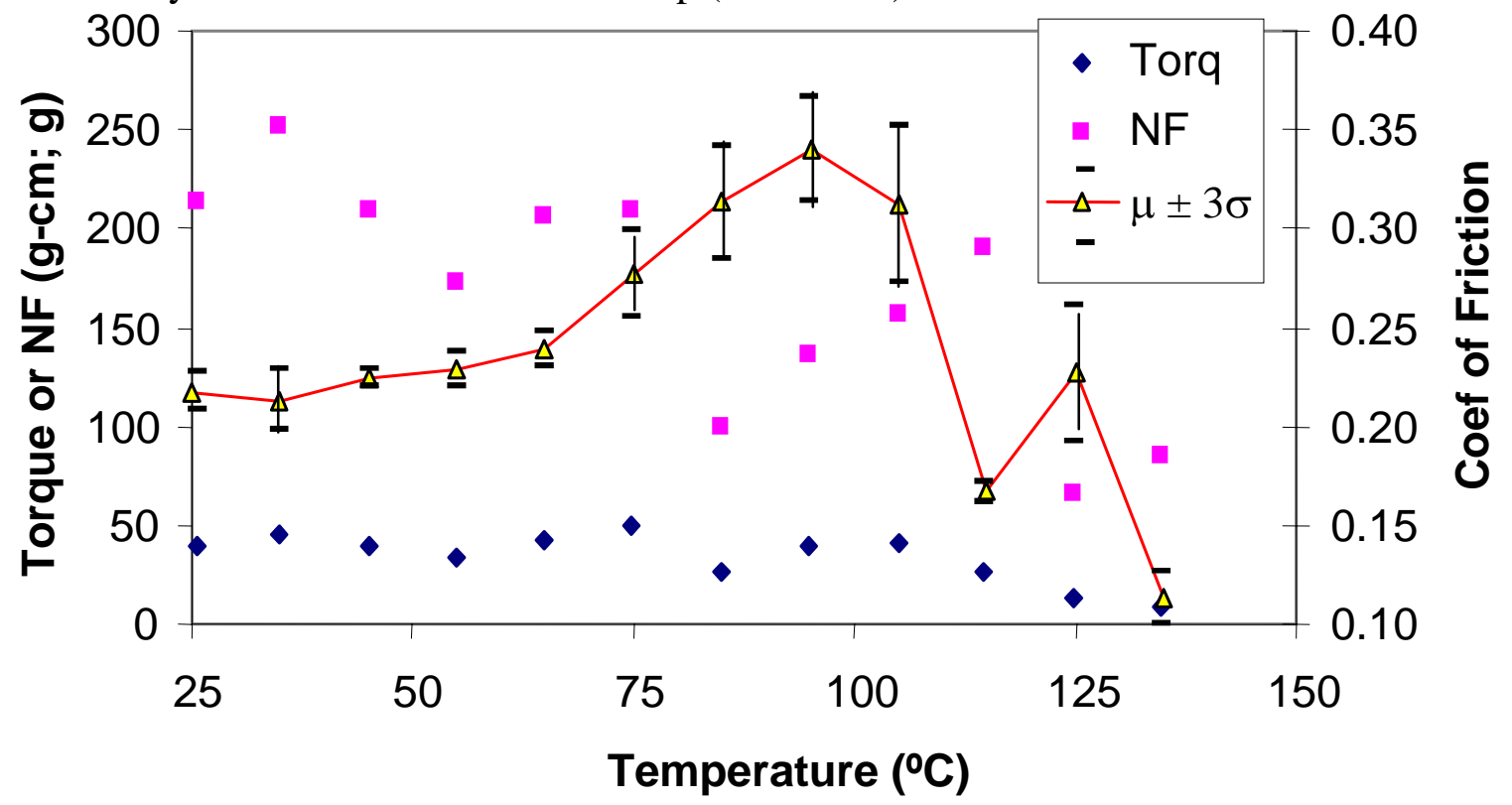

Figure 6. Average torque values followed the normal force for PBX 9404 on steel in the steady state region of the measurements. The coefficient of friction as a function of temperature was always relatively low, increasing initially and then dropping off slightly. 


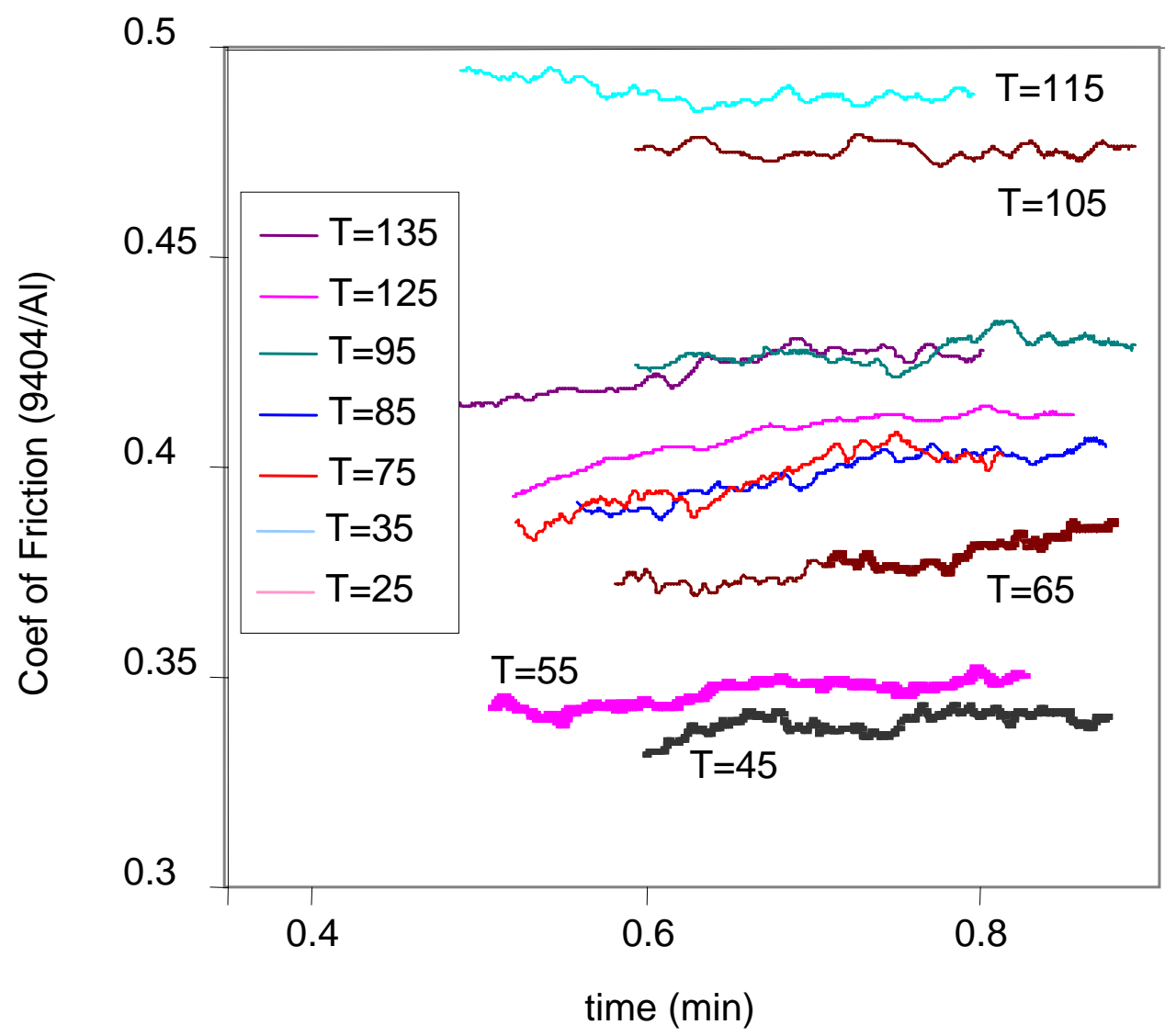

Figure 7. Estimates of the coefficient of friction for PBX 9404 on aluminum at each temperature were based on the average of the $3 \mathrm{~T} / 2 \mathrm{Nr}$ calculations and were nearly constant after an initial run up (not shown) while the cushion relaxed.

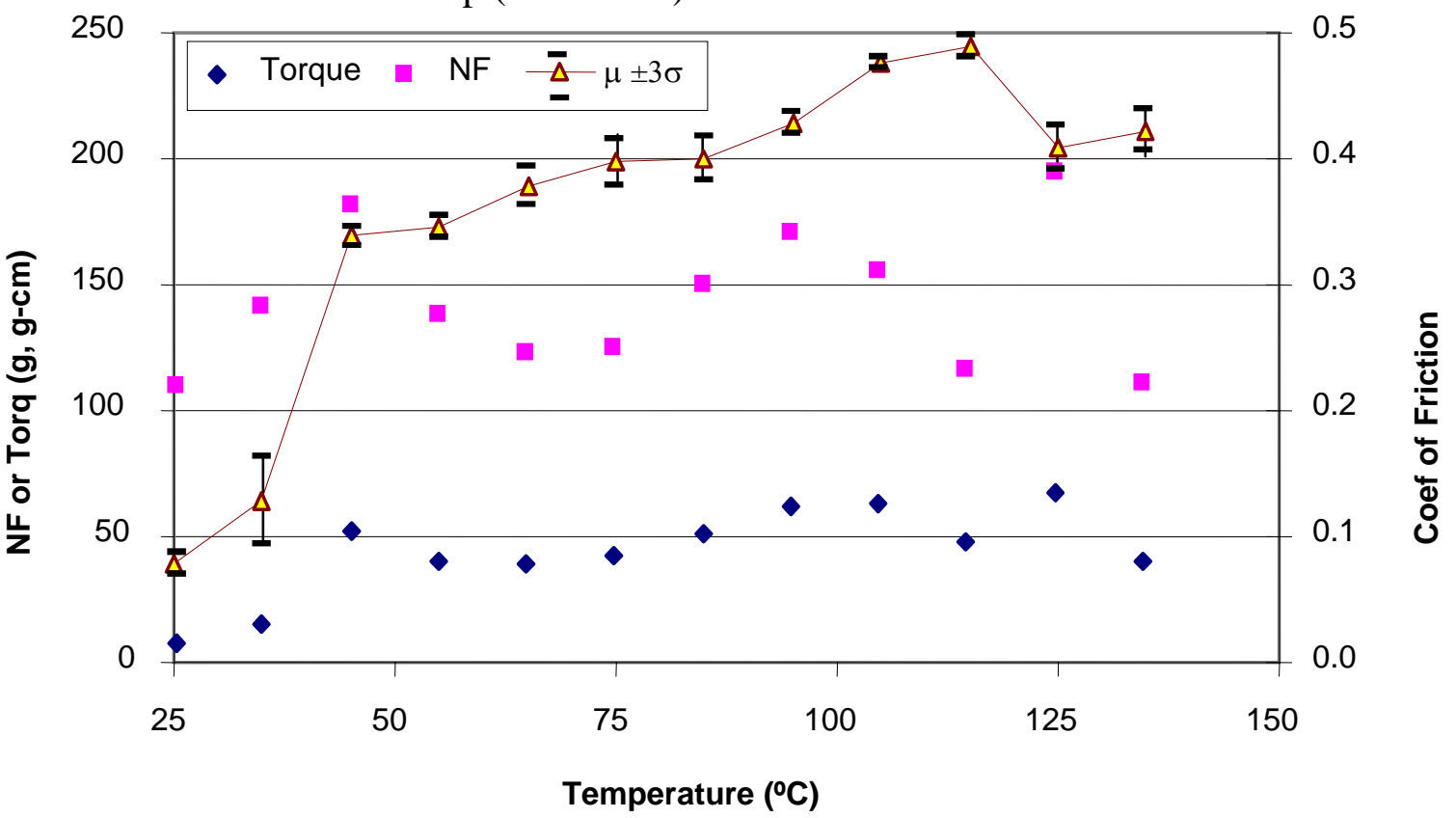

Figure 8. Coefficient of friction as a function of temperature of PBX 9404 on aluminum increased with temperature. Average normal force and torque data are shown also. 


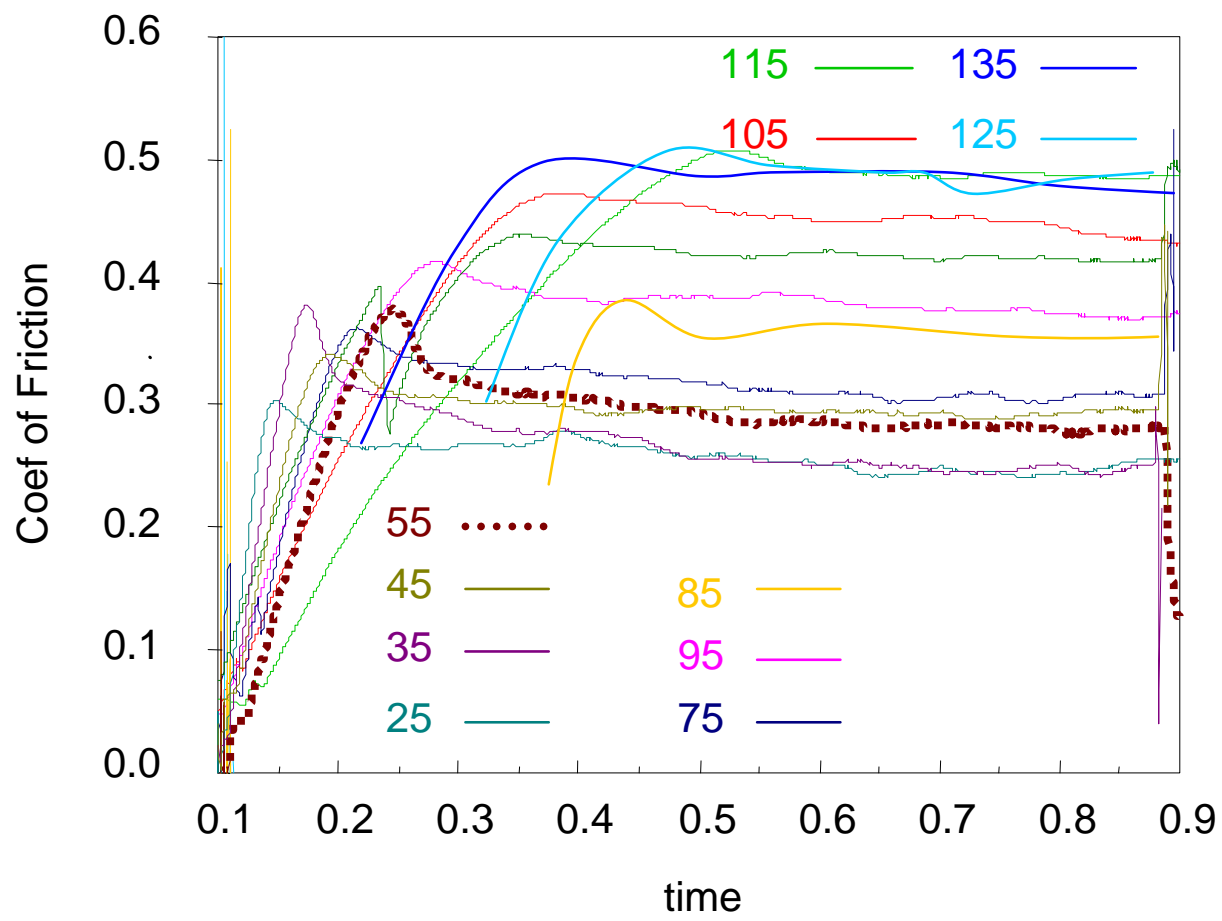

Figure 9. PBX 9404 coefficient of friction against PTFE showed both static and dynamic frictional behavior, especially at lower temperatures. The coefficient derived from the constant portion of these curves increased with increasing temperature. 


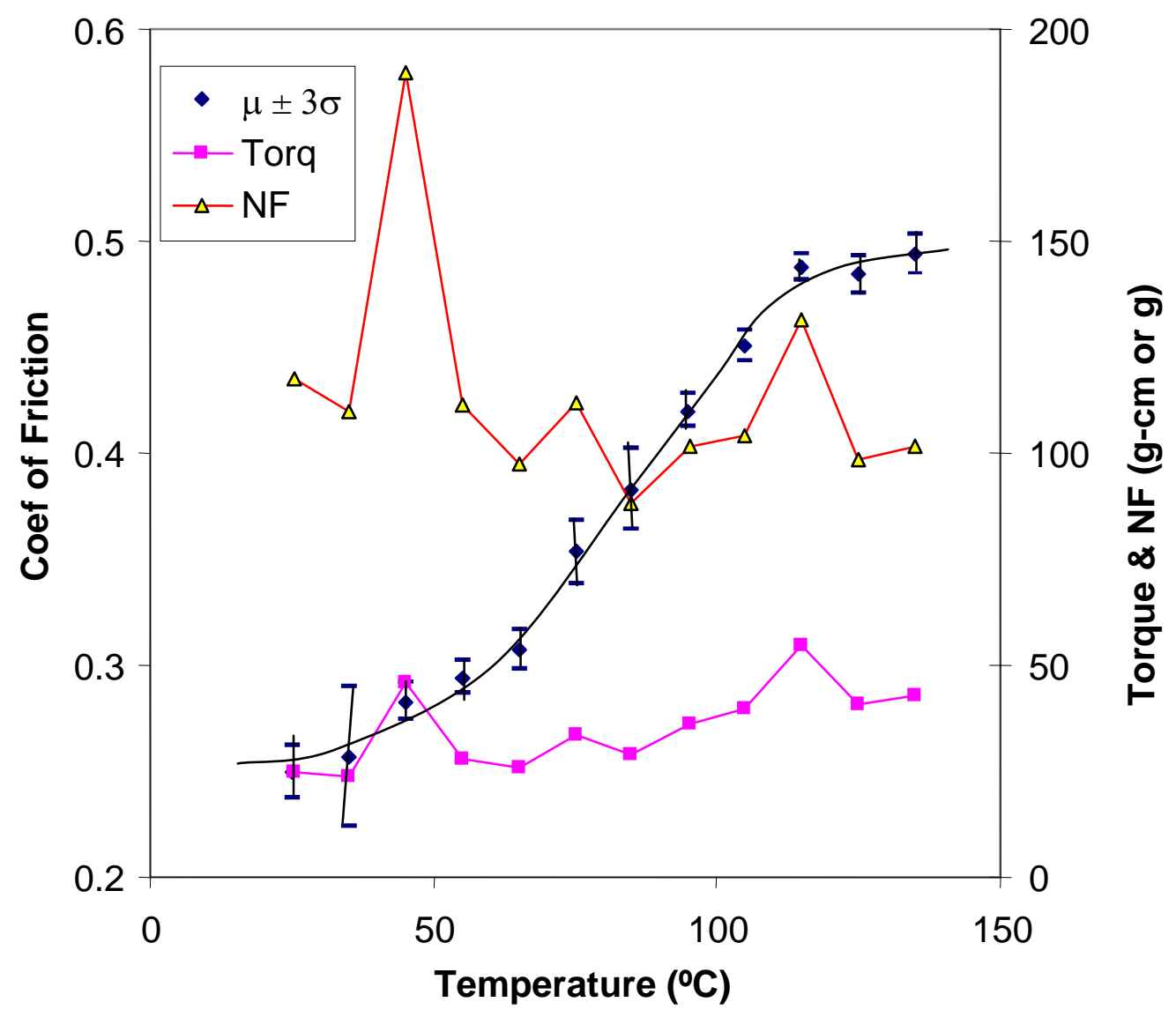

Figure 10. Calculated values of $\mu$ for PBX 9404 on etched PTFE increased with increasing temperature in a sigmoidal fashion between 45 and $115^{\circ} \mathrm{C}$. Torque and normal force values are also shown. 


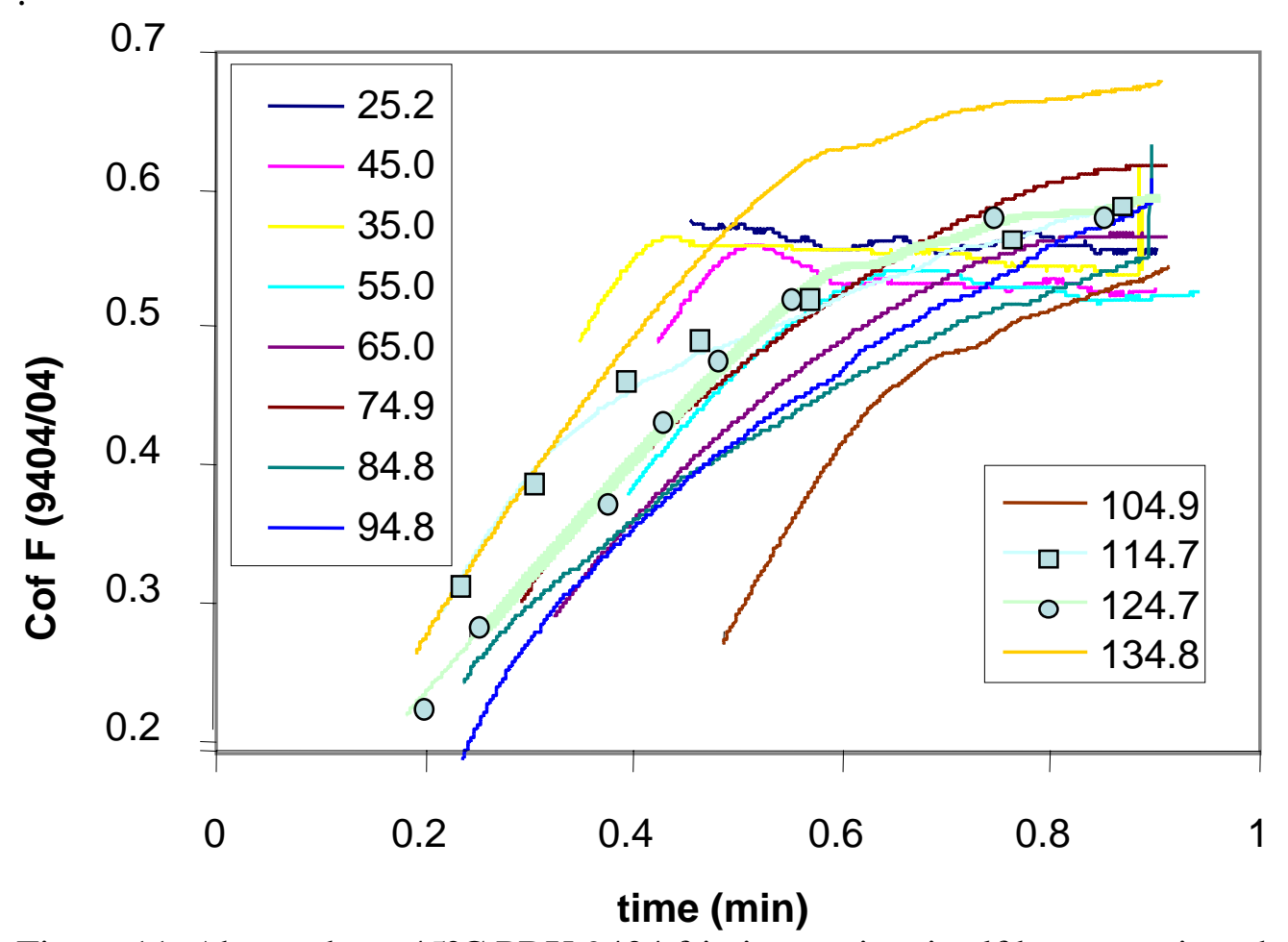

Figure 11. Above about $45^{\circ} \mathrm{C}$ PBX 9404 friction against itself becomes time dependent probably associated with adhesion of the polymer binder. Coefficients of friction estimated for PBX 94-04 on itself did not approach constant values over the 1 minute measurement intervals at temperatures between $45<\mathrm{T}<95^{\circ} \mathrm{C}$. 


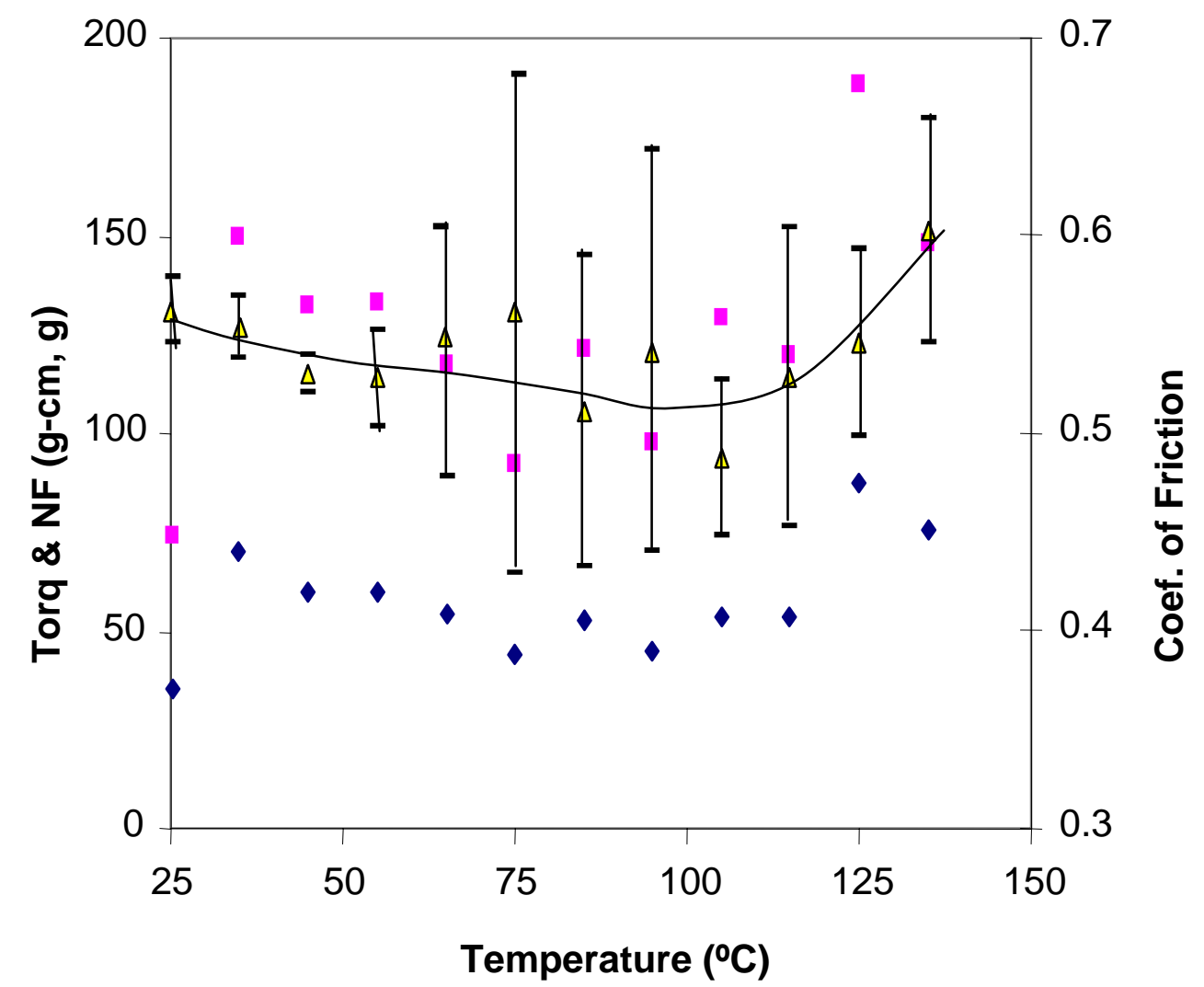

Figure 12. Average values of the coefficient of friction of PBX 9404 on itself were high and did not change dramatically over the temperature range from 25 to $135^{\circ} \mathrm{C}$. 
Appendix A - Dynamic coefficient of friction ( $\mu$ ) for 9404 on different counter surfaces as a function of temperature

\begin{tabular}{ccccc}
$\begin{array}{c}\text { Temp }\left({ }^{\circ} \mathrm{C}\right) \\
\text { Substrate }\end{array}$ & $\begin{array}{c}\text { Ave } \mu \\
\text { Aluminum }\end{array}$ & $\begin{array}{c} \pm \text { std.dev. } \\
\mathrm{Ra}=0.31 \mu \mathrm{m}\end{array}$ & $\begin{array}{c}\text { Ave } \mu \\
\text { Stainless }\end{array}$ & $\begin{array}{c} \pm \text { std.dev. } \\
\mathrm{Ra}=0.40 \mu \mathrm{m}\end{array}$ \\
\hline 25 & 0.0784 & 0.0027 & 0.2175 & 0.0032 \\
35 & 0.1281 & 0.0115 & 0.2133 & 0.0053 \\
45 & 0.3390 & 0.0025 & 0.2246 & 0.0016 \\
55 & 0.3459 & 0.0031 & 0.2291 & 0.0029 \\
65 & 0.3779 & 0.0049 & 0.2394 & 0.0029 \\
75 & 0.3976 & 0.0061 & 0.2769 & 0.0073 \\
85 & 0.3997 & 0.0057 & 0.3133 & 0.0096 \\
95 & 0.4282 & 0.0030 & 0.3396 & 0.0089 \\
105 & 0.4753 & 0.0015 & 0.3123 & 0.0132 \\
115 & 0.4893 & 0.0027 & 0.1669 & 0.0017 \\
125 & 0.4083 & 0.0056 & 0.2268 & 0.0114 \\
135 & 0.4219 & 0.0054 & 0.1129 & 0.0045 \\
\hline
\end{tabular}

\begin{tabular}{ccccc}
$\begin{array}{c}\text { Temp }\left({ }^{\circ} \mathrm{C}\right) \\
\text { Substrate }\end{array}$ & $\begin{array}{c}\text { Ave } \mu \\
\text { PTFE }\end{array}$ & $\begin{array}{c} \pm \text { std.dev. } \\
\text { Ra }=0.054 \mu \mathrm{m}\end{array}$ & $\begin{array}{c}\text { Ave } \mu \\
\text { PBX9404 }\end{array}$ & $\begin{array}{c} \pm \text { std.dev. } \\
\text { Ra=0. } \mu \mathrm{m}\end{array}$ \\
\hline 25 & 0.2496 & 0.0041 & 0.5621 & 0.0054 \\
35 & 0.2567 & 0.0109 & 0.5537 & 0.0053 \\
45 & 0.2828 & 0.0029 & 0.5295 & 0.0032 \\
55 & 0.2943 & 0.0026 & 0.5276 & 0.0082 \\
65 & 0.3076 & 0.0031 & 0.5487 & 0.0233 \\
75 & 0.3531 & 0.0048 & 0.5607 & 0.0439 \\
85 & 0.3827 & 0.0063 & 0.5110 & 0.0264 \\
95 & 0.4201 & 0.0026 & 0.5412 & 0.0339 \\
105 & 0.4506 & 0.0023 & 0.4878 & 0.0132 \\
115 & 0.4875 & 0.0020 & 0.5289 & 0.0253 \\
125 & 0.4844 & 0.0029 & 0.5464 & 0.0158 \\
135 & 0.4936 & 0.0032 & 0.6022 & 0.0189 \\
\hline
\end{tabular}




\section{DISCLAIMER}

This document was prepared as an account of work sponsored by an agency of the United States Government. Neither the United States Government nor the University of California nor any of their employees, makes any warranty, expressed or implied, or assumes any legal liability or responsibility for the accuracy, completeness, or usefulness of any information, apparatus, product, or process disclosed, or represents that its use would not infringe privately owned rights. Reference herein to any specific commercial products, process, or service by trade name, trade mark, manufacturer, or otherwise, does not constitute or imply its endorsement, recommendation, or favoring by the United States Government or the University of California. The views and opinions of authors expressed herein do not necessarily state or reflect those of the United states Government or the University of California and shall not be used for advertising or product endorsement purposes.

This work was performed under the auspices of the U.S. Department of Energy by the University of California, Lawrence Livermore National Laboratory under Contract No. W-7405-Eng-48 